\title{
Growing Environments and Micronutrients Application Influence Fruit and Seed Yield of Capsicum (Capsicum Annum)
}

\author{
Ankur Agarwal* \\ Defence Institute of Bio Energy Research, Min. of Defense, India
}

Submission: December 16, 2017; Published: January 31, 2018

*Corresponding author: Ankur Agarwal, Scientist 'D', Defense Institute of Bio-Energy Research, DRDO, Haldwani, Uttarakahnd-263139, India, Tel: 91-5946-232532; Fax: 91-5946-232800 extn: (*241); Email: ankur@darl.drdo.in

\section{Abstract}

Field experiments were carried out to standardize agro-techniques for higher productivity of capsicum in cold arid region of Ladakh. The experiments consisted of effect of growing environments (viz., under ground trench, polycarbonate green house, polyench and open condition) and micronutrients (zinc, boron, manganese, magnesium, and copper) spray on yield performance and quality of capsicum var. California Wonder, Pusa Deepti and Yolo Wonder. Results revealed the significant effect of growing environments on marketable traits of capsicum. Fruit yield was found maximum under triple layer polycarbonate greenhouse $(634.0 \mathrm{~g} / \mathrm{plant})$ exhibiting $115 \%$ increment over open control (294.0g/ plant). Among the micronutrients spray, two sprays of zinc $(100 \mathrm{ppm})$ or boron $(100 \mathrm{ppm})$ were found best under greenhouse conditions for obtaining higher yield and quality of capsicum exhibiting fruit yield of $840.96 \mathrm{~g}$ per plant significantly superior over control (768.43g per plant) irrespective of the variety. Interaction effects of micronutrients to variety were significant for marketable traits of capsicum. In case of seed recovery, polycarbonate greenhouse was found best exhibiting the highest seed yield ( 4.01 to $4.39 \mathrm{~g} / \mathrm{plant}$ ) with better test weight ( 5.62 to $5.76 \mathrm{~g}$ ).

Keywords: Greenhouse peppers; Capsicum annuum; Micronutrient; Fertilization; Protected cultivation

\section{Introduction}

Greenhouse grown capsicum (Capsicum annuum L.) is one of the remunerative crops in hilly areas of northern and southern India. It is a delicacy in the Indian culinary items and also a source of vitamins, minerals and antioxidants [1]. Its local availability in the Ladakh sector is very low and demand is met through transport from far areas which led to excessive losses and deterioration of quality due to its perishable nature [2]. Inclement weather, fluctuation in temperature and high winds in these hilly areas lead to its poor production in open fields [3]. Protected structures like polyhouse, polytunnels, and plastic mulches have been found very useful for growing capsicum in hilly areas [4-6] with high quality produce [7,8]. Secondly, soil of this region is not very fertile [9] therefore role of balanced nutrition become important to raise a good crop with higher productivity. Micronutrients, being a key component of IPNM and necessary for biosynthesis of several plant enzymes, have proved their importance in quality vegetable production in capsicum [10] , tomato [11], cucumber [12] , garlic [13] and cauliflower [14] . Micronutrients especially zinc and boron as an essential trace elements promote growth and development, flowering and fruiting [15-18]. No information is available on the effect of various structures on the productivity of this crop in this region as well as effect of micronutrients on fruit and seed production potential. Therefore, this study was carried out to standardize capsicum cultivation under protected structure in this region to ensure the availability of this crop, increase the productivity and extend the time of availability with better quality fresh fruits to the locals as well as to the armed forces deployed in this far flung region of the country.

\section{Materials and Methods}

\section{Experimental site and treatments}

The experiments were carried out at Field Research Laboratory Research Station at Partapur, Nubra valley, Siachen sector of Ladakh situated at about $9500 \mathrm{ft}$ above MSL. The temperature of this area varies from $-20{ }^{\circ} \mathrm{C}$ (Jan) to $32{ }^{\circ} \mathrm{C}$ (Aug). The average temperature during crop season varied from $14-20{ }^{\circ} \mathrm{C}(\max )$ and $4-6{ }^{\circ} \mathrm{C}(\min )$. The soil was sandy with $\mathrm{pH} 7.44$, electrical conductivity $0.13 \mathrm{mmhos} / \mathrm{cm}$, organic C $0.58 \%$, available $\mathrm{P}(10.05 \mathrm{~kg} / \mathrm{ha})$ and available $\mathrm{K}$ $(260 \mathrm{~kg} / \mathrm{ha})$, zinc $(2.68 \mathrm{ppm})$, copper $(1.87 \mathrm{ppm})$, iron (22.33) and manganese (32.06ppm). The first experiment consisted of four growing environments (viz., under ground trench, polycarbonate green house, polyench and open condition). Four-weeks-old seedlings of capsicum var California Wonder were transplanted during first week of May at a spacing of $45 \times 45 \mathrm{~cm}$ during both the years. The second experiment 
consisted of six micronutrient treatments, viz Mg (100ppm) as magnesium sulphate, $\mathrm{Cu}(100 \mathrm{ppm})$ as copper sulphate, Mn (100ppm) as manganese sulphate, Zn (100ppm) as zinc sulphate, $B(100 \mathrm{ppm})$ as borax, and control (no spray) on three varieties of capsicum viz., California Wonder, Pusa Deepti and Yolo Wonder. Four-weeks-old seedlings of all three capsicum cultivars were transplanted during first week of May at a spacing of $45 \times 45 \mathrm{~cm}$ in polycarbonate greenhouse. Two sprays of each were made after 30 and 45 days of transplanting in all the three replications. All recommended cultural practices were done uniformly in all the treatments of both experiments. The fertilizer dose of 100:80:60kg N:P:K/ha in the form of urea, DAP and muriate of potash was applied. Full dose of $\mathrm{P}$ and $\mathrm{K}$ along with half of the $\mathrm{N}$ was applied as basal while rest of the $\mathrm{N}$ was applied as top dressing in two splits after 30 and 45 days of transplanting.

\section{Statistical analysis}

Observations were recorded on plant growth and yield parameters along with seed recovery. Data were analyzed statistically as per the standard procedure.

\section{Details of the structures used}

Underground Trenches: This is the very simple, cheap and potentially useful structure. A trench of $30 \times 10 \times 3$ (Lx W x $\mathrm{H}) \mathrm{ft}$ was used to grow crop. The sides of the pit are adequately plastered with mud or mud bricks to avoid falling of the soil during cultural operations. Wooden or iron poles are used to support the UV stabilized polyethylene sheet of 200 mocron over the trench. Being an underground structure, it provides protections from winds, reduces heat loss during night hours and maintains better temperature during daytime thus allowing better growth and finally yield. Cultural operations are done by rolling over the polyethylene sheets.

Double-wall polyench: The term polyench is the abbreviation of a polyhouse constructed over a trench. The design of the structure is done by FRL (DRDO) Leh. The structure is made up of local material leading to low cost. The structure is of the shape of gable uneven span with sides of the structures are double-walled and made of mud bricks. Mud bricks are used as they provide better insulation and loose heat slowly compared to stone. The double walls are spaced at $15 \mathrm{~cm}$ and gap is filled with insulating material like saw dust to improve the heat retention. The side walls are descending towards the front till the ground level with the provision of gate towards the back wall. The roof is like uneven span greenhouse. The sun facing roof towards the south is larger than northern side roof. The sun facing roof is built with UV stabilized polyethylene/FRP sheet supported over a wooden frame whereas the other side roof is made of grass thatch with provision of ventilators. The inner sides of the walls are painted black to trap more heat. The back wall is $7 \mathrm{ft} \mathrm{high.}$

Polycarbonate greenhouse: A triple layered polycarbonate greenhouse $(10 \mathrm{~mm}$ thick) with more than 80 per cent light transmissibility with provision of side windows for natural ventilation was used for experimentation.

\section{Results and Discussion}

Analysis of variance revealed the significant effect of various protected structures on the horticultural traits and seed related traits of capsicum during both the years. The results also revealed that various protected structures exhibited the significant effect of their growing conditions on various horticultural and yield related traits during both the years (Table $1 \& 2$ ). Plant height was the minimum in open condition $(28.0 \mathrm{~cm})$ and the maximum under polyench $(95.67 \mathrm{~cm})$ followed by polycarbonate and trench (Table 3 ). Plant height was significantly superior under all protected structures. Interestingly, plants were excessively long under polyench but this may be attributed to the shade effect which is experienced by this structure due its partial underground nature and partial mud wall. Similar trend was noticed during second year also though the plant height was better under open conditions $(34.0 \mathrm{~cm})$ compared to first year (Table 4$)$. Number of fruits per plant also varied significantly under different growing structures with the maximum under polycarbonate (7.93 and 7.27, respectively) whereas the minimum under open condition (4.50 and 4.87, respectively) during both the years. No significant difference was noticed in the number of fruits per plant between polyench and open vis-à-vis polycarbonate and trench. During both the years, average fruits weight was the maximum under polycarbonate (90.4 and $92.67 \mathrm{~g}$ ) significantly superior over open condition and statistically at par with other two structures. Fruit size also affected significantly during both the years and the largest fruits were recorded under polyench $(8.10 \mathrm{~cm})$ during first year and under polycarbonate $(7.27 \mathrm{~cm})$ during second year significantly superior over open but statistically at par among the protected structures.

Table 1: ANOVA for various yield attributing traits in capsicum during first year

\begin{tabular}{|c|c|c|c|c|c|c|c|c|c|c|}
\hline Source & df & $\begin{array}{c}\text { Plant } \\
\text { height } \\
\text { (cm }\end{array}$ & $\begin{array}{c}\text { Fruits/ } \\
\text { plant }\end{array}$ & $\begin{array}{c}\text { Ave. Fruit } \\
\text { Wt (g) }\end{array}$ & $\begin{array}{c}\text { Fruit } \\
\text { length } \\
\text { (cm) }\end{array}$ & $\begin{array}{c}\text { Fruit } \\
\text { yield/ } \\
\text { plant (g) }\end{array}$ & $\begin{array}{c}\text { Seed: } \\
\text { Flesh } \\
\text { ratio }\end{array}$ & $\begin{array}{c}\text { Seeds/ } \\
\text { fruit }\end{array}$ & $\begin{array}{c}\mathbf{1 0 0 0} \\
\text { seed wt } \\
\text { (g) }\end{array}$ & $\begin{array}{c}\text { Seed } \\
\text { yield/ } \\
\text { plant (g) }\end{array}$ \\
\hline Replication & 2 & 9.65 & 0.21 & 31.25 & 0.025 & 1193.2 & 0.008 & 316.3 & 0.042 & 0.794 \\
\hline Treatment & 3 & $2476.2^{* *}$ & $9.83^{* *}$ & $487.8^{* *}$ & 1.17 & $71535^{* *}$ & 0.0036 & $1204.7^{* *}$ & $0.075^{*}$ & $5.525^{* *}$ \\
\hline Error & 6 & 44.65 & 0.85 & 37.11 & 0.427 & 7275.8 & 0.0009 & 62 & 0.0115 & 0.378 \\
\hline
\end{tabular}


Nutrition \& Food Science International Journal

Table 2: ANOVA for various yield attributing traits in capsicum during second year.

\begin{tabular}{|c|c|c|c|c|c|c|c|c|c|c|}
\hline Source & df & $\begin{array}{c}\text { Plant } \\
\text { height } \\
\text { (cm }\end{array}$ & $\begin{array}{c}\text { Fruits/ } \\
\text { plant }\end{array}$ & $\begin{array}{c}\text { Ave. Fruit } \\
\text { Wt (g) }\end{array}$ & $\begin{array}{c}\text { Fruit } \\
\text { length } \\
\text { (cm) }\end{array}$ & $\begin{array}{c}\text { Fruit } \\
\text { yield/ } \\
\text { plant (g) }\end{array}$ & $\begin{array}{c}\text { Seed: } \\
\text { Flesh } \\
\text { ratio }\end{array}$ & $\begin{array}{c}\text { Seeds/ } \\
\text { fruit }\end{array}$ & $\begin{array}{c}\mathbf{1 0 0 0} \\
\text { seed wt } \\
\text { (g) }\end{array}$ & $\begin{array}{c}\text { Seed } \\
\text { yield/ } \\
\text { plant (g) }\end{array}$ \\
\hline Replication & 2 & 24.08 & 0.225 & 9.75 & 0.145 & 759.1 & 0.0015 & 60.75 & 0.0023 & 0.16 \\
\hline Treatment & 3 & $1387.3^{* *}$ & $3.95^{* *}$ & $595.2^{*}$ & $0.323^{* *}$ & $67796^{* *}$ & $0.0059^{* *}$ & $1120.2^{* *}$ & 0.031 & $4.19^{* *}$ \\
\hline Error & 6 & 15.42 & 0.21 & 71.8 & 0.01 & 749.3 & 0.0003 & 77.96 & 0.0074 & 0.142 \\
\hline
\end{tabular}

* and ** indicate significant at 5 and $1 \%$ level of significance respectively

Table 3: Effect of various protected structures on yield attributing traits in capsicum during first year.

\begin{tabular}{|c|c|c|c|c|c|c|c|}
\hline Treatment & $\begin{array}{c}\text { Plant height } \\
\text { (cm) }\end{array}$ & Fruits/ plant & $\begin{array}{c}\text { Ave. Fruit Wt } \\
\text { (g) }\end{array}$ & $\begin{array}{c}\text { Fruit length } \\
\text { (cm) }\end{array}$ & $\begin{array}{c}\text { Seed: Flesh } \\
\text { ratio }\end{array}$ & $\begin{array}{c}\text { Seeds/fruit } \\
\text { 1000 seed wt } \\
\text { (g) }\end{array}$ \\
\hline Trench & 45.6 & 7.27 & 80 & 7.43 & 0.27 & 87.33 & 5.44 \\
\hline Polycarbonate & 52.57 & 7.93 & 90.4 & 6.8 & 0.22 & 99.67 & 5.76 \\
\hline Polyench & 95.67 & 4.5 & 90.2 & 8.1 & 0.19 & 84.67 & 5.58 \\
\hline Open & 28 & 4.5 & 63.2 & 6.8 & 0.21 & 52.67 & 5.42 \\
\hline SEm \pm & 5.46 & 0.75 & 4.97 & 0.533 & 0.03 & 6.43 & 0.08 \\
\hline CD (p=0.05) & 13.36 & 1.85 & 12.18 & 1.3 & NS & 15.75 & 0.21 \\
\hline
\end{tabular}

Table 4: Effect of various protected structures on yield attributing traits in capsicum during second year

\begin{tabular}{|c|c|c|c|c|c|c|c|}
\hline Treatment & $\begin{array}{c}\text { Plant height } \\
\text { (cm }\end{array}$ & Fruits/ Plant & $\begin{array}{c}\text { Ave. Fruit Wt } \\
\text { (g) }\end{array}$ & $\begin{array}{c}\text { Fruit length } \\
\text { (cm) }\end{array}$ & $\begin{array}{c}\text { Seed: Flesh } \\
\text { ratio }\end{array}$ & Seeds/ Fruit & $\begin{array}{c}\text { 1000 Seed wt } \\
\text { (g) }\end{array}$ \\
\hline Trench & 47 & 6.47 & 79.33 & 7.13 & 0.22 & 80 & 5.46 \\
\hline Polycarbonate & 57 & 7.27 & 92.67 & 7.27 & 0.25 & 98 & 5.62 \\
\hline Polyench & 84.7 & 5.07 & 83.67 & 7.13 & 0.21 & 70.3 & 5.48 \\
\hline Open & 34 & 4.87 & 59.33 & 6.53 & 0.15 & 51.6 & 5.38 \\
\hline SEm \pm & 3.21 & 0.37 & 6.92 & 0.08 & 0.014 & 7.21 & 0.07 \\
\hline CD (p=0.05) & 7.85 & 0.92 & 16.95 & 0.2 & 0.035 & 17.66 & NS \\
\hline
\end{tabular}

Fruit yield which is the most important trait for economics of the cultivation also affected significantly by the growing environment of the structures. The maximum fruit yield per plant was observed under polycarbonate house $(634.0 \mathrm{~g}$ and $630.0 \mathrm{~g}$, respectively) during both the years significantly superior over open where it was the lowest (294.0 and 286.0g) (Figure $1 \& 2$ ). The fruit yield under polycarbonate was also significantly superior over polyench during both the years and over trench during second year. The superiority in the fruit yield in polycarbote may be attributed to the more number of fruits per plant with comparatively heavier weight inside this structure compared to open condition and other structures. These findings suggest that protected structures of any kind is better over open condition in these area to grow capsicum because fruit yield increases from 32.5 (polyench) to $117.5 \%$ (polycarbonate) over control, pooled over two years. These findings also revealed that low cost protected structures like underground trenches are really better option for growing these vegetables as fruit yield increment is in the range of $85 \%$.
Capsicum enjoys assured market in Ladakh and fetches good price in market, therefore has vast potential [19]. Quality seed production is always a problem in open mostly due to lack of agro-techniques and secondly seedlessness of fruits grown outside in open due to low temperatures during night [2]. Protected environment provides opportunity to grow vegetables successfully for table purpose. Present findings revealed that seed related traits also affected significantly by growing structures. Seed to flesh ratio was better inside the protected structures. Average number of seeds per fruit was the minimum (52.67 and 51.6, respectively) under open condition whereas the maximum under polycarbonate $(99.67$ and 98.0, respectively) during both the years. This may be attributed to the smaller sized fruits obtained in open conditions which are ultimately the effect of poor weather conditions and fluctuating temperature. Seeds harvested from the protected structures were also bold as exhibited by the 1000 seed weight that was comparatively higher in protected structures over the open conditions. Seed yield per plant was 
found significantly higher under polycarbonate (4.39 and $4.01 \mathrm{~g}$, respectively) during both the years over open as well as polyench (Figure $1 \& 2$ ).

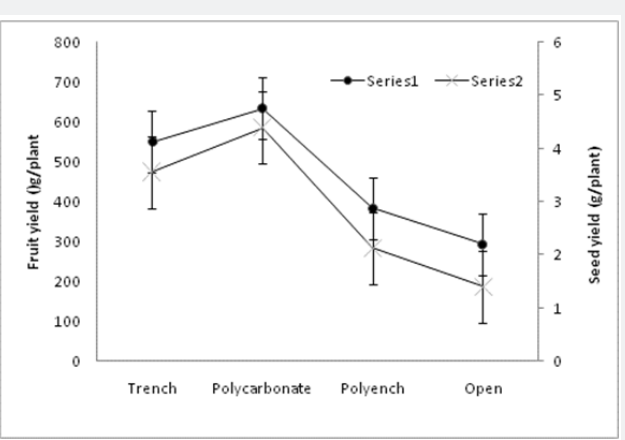

Figure 1: Effect of growing environments (Trench, polycarbonate, polyench and open) on fruit yield (series 1) and seed yield (series 2) of capsicum var California wonder during second year. Data presented in the average of five plants. Value of critical difference to compare the means for fruit yield is 54.75 and for seed yield id 0.75 at $P=0.05$. Error bars represent the standard error values.

Micronutrients, being a key component of IPNM and necessary for biosynthesis of several plant enzymes, have proved their importance in quality vegetable production. Analysis of variance revealed the significant effect of micronutrient spray, variety and their interaction on the quantitative traits of the capsicum. Spray of micronutrients exhibited increase in number of fruits per plant compared to control in all three varieties of capsicum (Table $5 \& 6$ ). The average value for the trait was the maximum under zinc spray. Average fruit weight also exhibited the beneficial effect of micronutrient spray over control. The value averaged over all three varieties exhibited that zinc spray treatment resulted into heavier fruits. Fruit yield per plant varied from 681.7 to

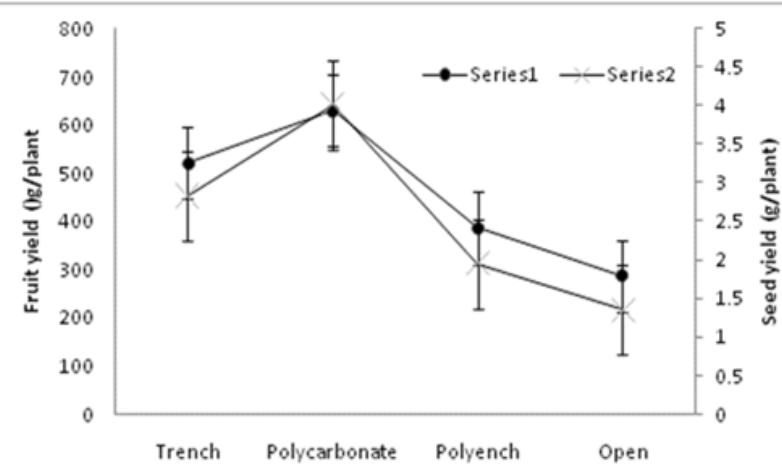

Figure 2: Effect of growing environments (Trench, polycarbonate, polyench and open) on fruit yield (series 1 ) and seed yield (series 2) of capsicum var California wonder during first year. Data presented in the average of five plants. Value of critical difference to compare the means for fruit yield is 170.63 and for seed yield is 1.23 at $P=0.05$. Error bars represent the standard error values.

758.0g for California wonder, 782.3 to $842.6 \mathrm{~g}$ for Pusa Deepti and 841.3 to $922.3 \mathrm{~g}$ for Yolo wonder under various treatments (Figure 3 \& 4). Fruit yield was the minimum under control and the maximum in zinc spray treatment. It is clear from the results that among the micronutrients, zinc (100ppm) spray twice before onset of flowering is beneficial in increasing the marketable yield by $10-13 \%$ and size of fruits in capsicum. Beneficial effect of zinc sulphate $(0.4 \%)$ and boric acid $(0.1 \%)$ has been reported in garlic by Srivastava et. al. Improvement in the fruit weight and size due to spray of micronutrients may be attributed to the role of these elements in the plant nitrogen metabolism, carbohydrate metabolism and translocation of photosynthates as reported by $[10,11,15,16,20,21]$.

Table 5: Effect of micronutrients spray on capsicum grown in polycarbonate greenhouse during I year.

\begin{tabular}{|c|c|c|c|c|c|c|}
\hline Treatment & $\begin{array}{c}\text { No. of fruis/ } \\
\text { plant }\end{array}$ & & & Ave. fruit wt (g) & & \\
\hline & $\mathrm{CW}$ & $\mathrm{PD}$ & YW & $\mathrm{CW}$ & PD & YW \\
\hline Control & 11.6 & 12.6 & 11 & 60.7 & 71.8 & 92.2 \\
\hline $\operatorname{Mg}(100 \mathrm{ppm})$ & 12.1 & 12.9 & 11.7 & 65.7 & 72.9 & 94.8 \\
\hline $\mathrm{Cu}(100 \mathrm{ppm})$ & 12.4 & 13.2 & 12.1 & 63.4 & 74.2 & 112.5 \\
\hline $\mathrm{Mn}(100 \mathrm{ppm})$ & 12.4 & 12.9 & 12.1 & 61.2 & 75.5 & 108.9 \\
\hline $\mathrm{Zn}(100 \mathrm{ppm})$ & 12.6 & 13.5 & 12.3 & 67.2 & 78.5 & 113.2 \\
\hline B (100 ppm) & 12 & 12.8 & 11.2 & 62.9 & 74.2 & 105.1 \\
\hline \multirow[t]{3}{*}{ LSD $(\mathrm{P}<0.05)$} & Variety $=0.306$ & & & Variety $=7.26$ & & \\
\hline & $\begin{array}{c}\text { Micronutrients }= \\
0.433\end{array}$ & & & $\begin{array}{c}\text { Micronutrients }= \\
10.27\end{array}$ & & \\
\hline & $\begin{array}{c}\text { Interaction }= \\
0.749\end{array}$ & & & $\begin{array}{c}\text { Interaction }= \\
17.80\end{array}$ & & \\
\hline
\end{tabular}


Nutrition \& Food Science International Journal

Table 6: Effect of micronutrients spray on capsicum grown in polycarbonate greenhouse during II year.

\begin{tabular}{|c|c|c|c|c|c|c|}
\hline Treatment & $\begin{array}{c}\text { No. of fruis/ } \\
\text { plant }\end{array}$ & & & Ave. fruit wt (g) & \\
\hline & CW & PD & YW & CW & PD & YW \\
\hline Control & 12 & 12.3 & 10.6 & 56.9 & 53.7 & 71.2 \\
\hline $\mathrm{Mg}(100 \mathrm{ppm})$ & 12 & 12.7 & 11.3 & 60.7 & 58.2 & 72.5 \\
\hline $\mathrm{Cu}(100 \mathrm{ppm})$ & 12.7 & 13 & 11.7 & 63.7 & 61.9 & 79.9 \\
\hline $\mathrm{Mn}(100 \mathrm{ppm})$ & 12.5 & 12.8 & 12.1 & 62.2 & 60.5 & 80.3 \\
\hline $\mathrm{Zn}(100 \mathrm{ppm})$ & 12.6 & 13.4 & 12 & 64.1 & 58.5 & 82.1 \\
\hline $\mathrm{B}(100 \mathrm{ppm})$ & 12 & 12.9 & 11.3 & 62.5 & 62.7 & 80.5 \\
\hline $\mathrm{LSD}(\mathrm{P}<0.05)$ & Variety $=0.958$ & & & Variety = 1.88 & & \\
\hline & $\begin{array}{c}\text { Micronutrients } \\
0.677\end{array}$ & & & Micronutrients \\
$=2.66$ & & \\
\hline & Interaction $=1.65$ & & & Interaction $=4.60$ & & \\
\hline
\end{tabular}

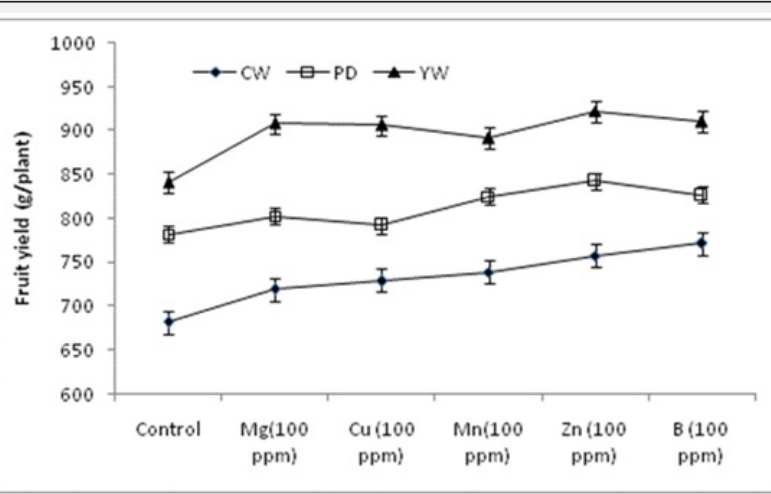

Figure 3: Effect of micronutrient spray of fruit yield of capsicum variety California Wonder (CW), Pusa Deepti (PD) and Yolo Wonder (YW) under polycarbonate house during first year. Values presented are mean of five plants. Factorial analysis revealed LSD values $(p<0.05)$ for Variety $=50.19$, Micronutrients $=70.97$ and Interaction $=122.94$. Error bars re present the standard error values.

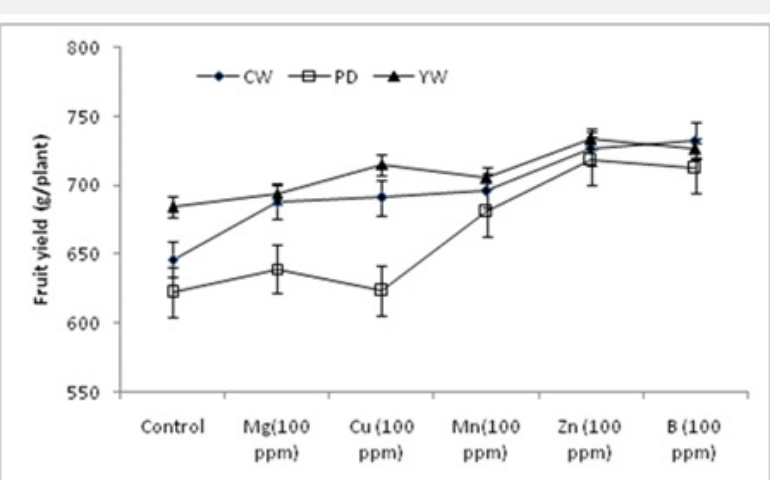

Figure 4: Effect of micronutrient spray of fruit yield of capsicum variety California Wonder (CW), Pusa Deepti (PD) and Yolo Wonder (YW) under polycarbonate house during second year. Values presented are mean of five plants. Factorial analysis revealed LSD values $(p<0.05)$ for Variety $=14.25$, Micronutrients $=20.15$ and Interaction $=34.91$. Error bars re present the standard error values.

\section{Conclusion}

The study revealed that protected conditions are better for fruit and seed yield of capsicum in higher altitude. Fruit yield was found maximum under triple layer polycarbonate greenhouse exhibiting $115 \%$ increment over open control. Among the micronutrients spray, two sprays of zinc (100ppm) or boron (100ppm) were found best under greenhouse conditions for obtaining higher yield and quality of capsicum irrespective of the variety. Interaction effects of micronutrients to variety were significant for marketable traits of capsicum. In case of seed recovery, polycarbonate greenhouse was found best exhibiting the highest seed yield with better test weight. Therefore farmers can motivated to use protected cultivation technology may it be low cost to have remunerative crop with spray of micronutrients to increase the fruit and seed quality.

\section{Acknowledgement}

Author acknowledges the support offered by technical staff and guidance by Dr Z. Ahmed, the then Director Leh to conduct the study.

\section{References}

1. Poulos JM (1993) Pepper Breeding. In: Breeding of Solanaceous and Cole crops. In: Chadha et al. (Eds.), AVRDC, Taiwan, pp. 85-121.

2. Agarwal A (2010) Vegetable Seed Production. In: D Dwivedi et al (Eds.), Agro-animal Resources of Higher Himalayas.), Satish Serial Publishing, New Delhi, India, pp. 53-84.

3. Singh B, Singh N, Singh DV (2000) Prospectus of vegetable production in Ladakh. In: Sharma JP\& Mir AA (Eds.), Dynamics of Cold Arid Agriculture, Kalyani Publishers, New Delhi, India, p. 85-98.

4. Singh B (1995) Vegetable Production in Ladakh. Field Research Laboraory (DRDO), C/0 56 APO, pp. 67.

5. Chandra P, Sirohi PS, Behera TK, Singh AK (2000) Cultivating vegetable in polyhouse. Indian Horticulture 45: 17-32.

6. Singh AK, Singh B, Gupta R (2011) Performance of sweet pepper (Capsicum annum) varieties and economics under protected and open field conditions in Uttarakhand. Indian J Agric Sci 81: 973-975.

7. Kurubetta Y, Patil AA (2009) Performance of coloured Capsicum hybrids under different protected structures. Karnataka J Agric Sci 22: 1058-1061.

8. Farooq M, Ramzan A, Chattha MR, Qasim U, Nawab NN (2015) Studies on the Performance of Sweet Pepper (Capsicum annum L.) Hybrids under Plastic Tunnel. Science, Technology and Development 34(3): 155-157. 
9. Singh B (2010) Introduction to Higher Himalayas. In: Dwivedi D, et al. (Eds.), Agro-animal Resources of Higher Himalayas, Satish Serial Publishing, New Delhi, India, p. 1-14.

10. Pal RK, Behra TK, Sen N, Singh M (2004) Response of bell pepper cultivars to foliar application of magnesium boron and zinc. Veg Sci 31: 40-44.

11. Kaya C, Higgs D (2002) Response of tomato cultivars to foliar application of zinc when grown in sand culture at low zinc. Scientia Hort 93: 53-64.

12. Dursun A, Turan M, Ekinci M, Gunes A, Ataoglu N, et al.,(2010) Effects of boron fertilizer on tomato, pepper, and cucumber yields and chemical composition. Communications in Soil Science and Plant Analysis, 41(13): 1576-1593.

13. Srivastava R, Agarwal A, Tiwari RS, Kumar S (2005) Effect of micronutrients, zinc and boron on yield, quality and storability of garlic (Allium sativum). Indian J Agric Sci 75: 157-159.

14. Agarwal A, Ahmed Z (2007) Response of cauliflower (Brassica oleracea var botrytis sub var cauliflora) to micronutrients application in high altitude cold desert of Ladakh. Indian Journal of Agricultural Sciences 77(24): 104-105.
15. Marschner H (1995) Mineral nutrition of higher plants. ( $2^{\text {nd }}$ edn) Academic Press San Diago, pp. 379-396.

16. Sweitlik D (1999) Zinc nutrition in horticultural crops. Horticultural Reviews, John Willey and Sons Inc, New York, USA, pp. 109-180.

17. Mello SC, Dechen Antonio R, Minami K (2002) Influence of boron application on sweet pepper development and mineral. J Hortic Bras 20(1): 99-102.

18. Huang JS, Snapp SS (2004) The effect of boron, calcium, and surface moisture on shoulder check, a quality defect in fresh-market tomato. J Ame Soc Hort Sci 129(4): 599-607.

19. Agarwal A, Gupta S, Ahmed Z (2007) Influence of plant densities on productivity of bell pepper under greenhouse in high altitude cold desert of Ladakh. Acta Horticulturae 756: 309-314.

20. Sakr MT (1992) Physiological aspects of sweet pepper plant affected by certain micronutrients and growth substances. J Agric Sci (Mansoura Uni) 17: 2958-2963.

21. Kanwar MS, Mir MS, Lamo K, Akbar PI (2014) Effect of protected structures on yield and horticultural traits of bell pepper (Capsicum annuum L.) in Indian cold arids. Afr J Agric Res 9(10): 874-880.

\section{Your next submission with Juniper Publishers will reach you the below assets}

- Quality Editorial service

- Swift Peer Review

- Reprints availability

- E-prints Service

- Manuscript Podcast for convenient understanding

- Global attainment for your research

- Manuscript accessibility in different formats

(Pdf, E-pub, Full Text, Audio)

- Unceasing customer service

Track the below URL for one-step submission https://juniperpublishers.com/online-submission.php 